\title{
Electricity Generation from the Foot Beats of Dancers at Club Centres in Awka, Anambra State
}

\author{
Godwin Chukwunonyelum Nworji ${ }^{1}$, Peter Uchenna Okoye ${ }^{2, *}$, Uche V. Okpala ${ }^{3}$ \\ ${ }^{1}$ Technology Incubation Centre Port Harcourt, National Board for Technology Incubation, Federal Ministry of Science and Technology, \\ Nigeria \\ ${ }^{2}$ Department of Building, Nnamdi Azikiwe University, Awka, Nigeria \\ ${ }^{3}$ Department of Industrial Physics, Chukwuemeka Odumegwu Ojukwu University, Uli, Anambra State, Nigeria
}

Received January 8, 2020; Revised March 23, 2020; Accepted March 28, 2020

Copyright $\bigcirc 2020$ by authors, all rights reserved. Authors agree that this article remains permanently open access under the terms of the Creative Commons Attribution License 4.0 International License

\begin{abstract}
The study designed and developed a system of generating electricity through the beats of human feet using piezoelectric materials. The system made use of mechanical deformation occasioned by the foot beats of dancers when stepped on a platform in which piezoelectric materials were installed at dance club centres to cause piezo films to generate electrical density that was stored in a rechargeable lead acid battery for future use. The study shows that human pressure due to human weight when applied in the system could be converted to electrical energy for later use. The study shows that it would require 1802 foot beats for a $50 \mathrm{~kg}$ dancer to increase a unit voltage in a battery; foot beats for a $60 \mathrm{~kg}$ dancer; and 1194 foot beats for an $80 \mathrm{~kg}$ dancer respectively. The system is suitable where there are high volumes of human traffic such as markets, worship centres, shopping malls, bus stations, and parks. It can also be used in powering small electrical appliances and electronic gadgets such as cell phones, radio stereo, television, fan, and street lights. Based on this, research into this kind of electricity generation should be expanded in large scale and sponsored by the government or corporate organisations. The system should be incorporated in the design and construction of building including new material development as a means of achieving sustainable construction and minimisation of conventional energy consumption in building use.
\end{abstract}

Keywords Club Centres, Electricity Generation, Foot Beats, Piezoelectric, Renewable Energy, Sustainable Building

\section{Introduction}

The socio-economic development of any country is largely dependent on the availability and accessibility of electricity [1-3]. The sustainability and defossilisation of today's energy systems to guard against the impacts of climate change in Nigeria have also been advocated [4,5].

As the population of Nigeria continue to grow, so also the electricity demand and consumption. In Nigeria, there are severe electricity problems due to non-availability, non-accessibility and non-affordability of electricity provision in the country $[6,7]$. The effects of this are untold, and play a major part in the developmental status of Nigeria [8-10]. The Federal Government report on the Nigerian power sector investment opportunities and guidelines also shows a complex problem where there is huge gap between supply and demand in the Nigeria power system [11]. The Advisory Power Team [12] categorises these challenges into generation, primary energy-gas, transmission and distribution problems.

In Awka the capital of Anambra State, the electricity situation is not better. Studies have shown that lack of steady electricity is the bane of problems of small, medium and large scale industries [13-16]. But the small scale businesses suffer the most. There are many small scale business outfits springing in Awka the capital of Anambra State in recent years. These business outfits include night club centres which are growing in number on daily basis.

Every day and night, there are thousands of people visiting these centres for night clubbing. However, the amount of electricity consumed in the course of running club business in Awka is outrageous compared to the revenue generated from it. This is because the business is usually carried out at night. The activities of night clubbing involve locomotive movements in terms of dancing. As the dancers dance, energy is being wasted in the process. Unfortunately, little or nothing have been done to conserve or convert the energy into useful state, while the events are 
being run using electricity generating set to provide electricity or on a very high electricity tariff. This condition brings little or no profit to the business outfit, thereby leading premature closure of most of these businesses.

Interestingly, there are many potential alternative and renewable sources energy in Nigeria [17]. The commonly known sources include: solar, wind, hydro, biomass and geothermal energy. However, the power needs of Nigeria have continued to increase and could not be met by the available energy sources, thus the need for more avenues through which electricity could be generated.

With advancement in technology, and the growing quest for more sustainable sources of energy, research has shown that mechanical energy could be converted to electrical energy for use in buildings and other outdoor and indoor centres through the human foot beats [18-24]. This is in an effort to complement the existing sources of energy. Notwithstanding, Nigeria has not practically delved into robust research in this area which has the potential of ameliorating the electricity problems of our people especially for small scale electricity consumption.

Most unfortunately, human energy that could have been converted into electrical energy for use at least by the small scale business outfits, markets religious centres, event centres, club houses, bus stations and parks, etc., are being wasted on daily basis. The ability to develop this system of generating electricity through the human foot beats as an alternative to conventional electricity supply could go a long way to boosting the economic potential of country. Therefore, this study was aimed at developing a system of generating electricity through the foot beats of dancers for dance clubs in Awka Anambra State.

\section{Literature Review}

Studies into alternative and renewable source of energy in Nigeria have been robust [9,10,25-32], however, these studies principally focused on the well-known form of energy sources such as solar, hydro, wind, thermal and biomass. Ohimain [8] and Sambo [33] had acknowledged the limiting factors to efficient and effectiveness of these renewable energy sources; thus, the need for efficient, effective, environmentally friendly and sustainable source of electricity generation in Nigeria.

But as we continue to dissipate energy in our daily activities including during our leisure time while walking, running or dancing, the energy could be converted to a more useful form of electrical energy. Available studies showed that this form of energy system have only been identified and developed in the developed and Asian countries. For example, Kamlesh et al. [34] developed a system through which power could be produced through human footsteps as a source of renewable energy that can be obtained while walking or standing on a certain arrangement like footpaths, stairs, plate forms and can be install specially in the more populated areas. Al-Qadhi et al. [35], Sabarish and Kumar [36] and Upadhyaya and Upadhyaya [37] equally designed a crankshaft mechanism as a mechanical arrangement installed on the stair case to convert the foot power applied on stairs, as a rotary motion into electrical energy, stored in a battery used for activating the connected loads.

Ang et al. [19] experimented the conversion from kinetic energy to electricity energy by placing a mechanical footstep power generator on the hind foot region using 45 individuals and compared the experiment results with the theoretical results. The result showed that generated power increased proportionally with the mass of an individual and that the actual power generated from experiments were higher than the theoretical results.

Babu et al. [20] developed a power generating slab using mechanical parts consisting of top plane, Rack and Pinion arrangement, Gear mechanism, springs, Shaft and Freewheeling bearing with dynamo fed into electrical system consisting of Converter, battery and Inverter units which can be used for emergency backup power, charging purpose and to run small electrical equipments during load shedding conditions.

Abhishek and Shivasharana [38], Bhosale et al. [39], Kotadiya and Parmar [40], Munaswamy et al. [41] and Sahoo et al. [42] also designed a footsteps system that generated electricity with the help of rack and pinion arrangement along with alternator and chain drive mechanism connected to a battery for storage.

Saeed et al. [23] employed ansys17.0 software to show in a simulation how about $10.925 \mathrm{kw}$ power could be produced in one hour using a footstep power generation mechanism that produces electricity by moving the human on a moving plates in which rack and pinion gear are used to convert the physical energy into mechanical energy and further into electric energy using a dynamo.

In their study, Aman et al. [43] developed a model that can generate 1 megawatt of power with a 100 floor on just twelve footsteps and it is capable of generating $10000 \mathrm{w}$ power for just 120 footsteps. This system can be installed on road side footpath, parks and jogging tracks and many other public place, airport etc. Similar model had also been developed by Shiraz and Farrukh [ 24].

On the other hands, Chavan et al. [44], Dhimar et al. [45] and Madhu et al. [46] designed a foot step power generation platform using piezoelectric sensors that generates electricity using the pressure due to weight of the person walking on the platform and stored using batteries. Marshiana et al. [47] proposed a novel technique for the creation of power utilising piezoelectric sensors kept along the footpaths which can charge the battery and supply the force at whatever time of our prerequisite. A similar technique that is capable of generating $40 \mathrm{~V}$ of electricity was devised by Anooj et al. [48], while Gopinath et al. [49] proposed a power generation technique through piezo sense and treadmill stride control generator framework that 
uses the piezoelectric sensors to produce control through strides as a wellspring of sustainable power source that can be gotten while strolling on a specific course of action like venturing foot on piezo tiles. The same technique was also designed by Naresh et al. [50], but together with microcontroller.

The forgoing studies demonstrated the different means through which electricity could be generated through the human foot beats. However, Hofstede [51] argued that the applicability of western cultures and technologies across countries due to cultural differences makes them implausible. In addition, since the amount of voltage, current and power generated through piezoelectric material is dependent on the pressure and weight of person [24], it is argued that more pressure would be exerted on the piezoelectric platform when one is dancing or jumping as it's the case of clubbers than walking. It is against this background that this study seeks to generate electricity through the beats of human feet as a renewable and sustainable alternative to other forms of electricity generation source for dance clubs in Awka Anambra State.

\section{Methodology}

Foot step power generation can be done through various techniques and methods like piezoelectric sensors, mechanical arrangement like fly wheel, gear wheel, rack \& pinion and chain sprocket arrangement, pedal and springs type arrangement, and staircase energy generating system by rotating the generator. In this study, piezoelectric system was used to develop a technique of generating energy from the foot beats of dancers in a dance club.

\subsection{Materials}

Materials used in this study include: $300 \mathrm{~mm} \times 300 \mathrm{~mm} x$ $25 \mathrm{~mm}$ thick wooden board, 3mm thick plywood of the same dimension, $150 \mathrm{~mm} \times 150 \mathrm{~mm}$ electric unit box, human weight of different kilogrammes, electric panel, foam spring, Lead Zirconate Titanate (PZT) piezoelectric sensors, rectifier (diodes), capacitors, resistors, 6V4AH Lead acid rechargeable battery, multimeter, AC nipple neutraliser, current controllers (switches), electric strand wire, LED and USB output.

\subsection{General Arrangement, Procedure and Working Principle}

A sheet of plywood measuring $300 \mathrm{~mm} \times 300 \mathrm{~mm} \times 3 \mathrm{~mm}$ thick was placed on a hard wooden board of $300 \mathrm{~mm} x$ $300 \mathrm{~mm}$ x $25 \mathrm{~mm}$ thick. On this board, twelve piezoelectric sensors were placed because the power output from one piezo film was found to be very low. However, the PZT-5 sensors were used because of their high piezoelectric properties [52-54]. The physical characteristics and electrical specifications of the PZT sensors are presented in
Table 1, while the arrangement of piezo sensors and connections in the system are shown in Figure 1.

Table 1. Specifications of piezoelectric sensor discs

\begin{tabular}{|c|c|c|c|}
\hline $\mathbf{S} / \mathbf{N}$ & Properties & Symbol & Value \\
\hline A. & \multicolumn{3}{|l|}{ Physical Properties } \\
\hline 1. & Diameter (mm) & & 10 \\
\hline 2. & Thickness (mm) & & 1 \\
\hline 3. & Hardness & & Hard \\
\hline 4. & Density(g/cm3) & $\rho$ & 7.5 \\
\hline 5. & Curie Temperature $\left({ }^{\circ} \mathrm{C}\right)$ & Tc. & 225 \\
\hline 6. & Mechanical Quality Factor & $\mathrm{Q}_{\mathrm{m}, \mathrm{p}}$ & 70 \\
\hline B. & \multicolumn{3}{|l|}{ Dielectric Properties } \\
\hline 1. & Dielectric Constant at $1 \mathrm{KHz}$ & $\mathrm{K}_{3} \mathrm{t}$ & 2600 \\
\hline 2 & Dissipation factor at $1 \mathrm{KHz}$ & $\tan \delta$ & 0.02 \\
\hline 3. & Resistivity & $\Omega-\mathrm{cm}$ & $10-12$ \\
\hline C. & \multicolumn{3}{|l|}{ Electro-Mechanical Data } \\
\hline 1. & Planer coupling co-efficient & $\mathrm{K}_{\mathrm{p}}$ & 0.62 \\
\hline 2. & Transverse coupling co-efficient & $\mathrm{K}_{31}$ & 0.37 \\
\hline 3. & Longitudinal coupling co-efficient & $\mathrm{K}_{33}$ & 0.72 \\
\hline \multirow{2}{*}{4.} & \multirow{2}{*}{$\begin{array}{l}\text { Piezoelectric } \\
\left(\mathrm{C} / \mathrm{NX} 10^{-12}\right)\end{array}$} & $-\mathrm{d}_{31}$ & 195 \\
\hline & & $\mathrm{d}_{33}$ & 460 \\
\hline \multirow{2}{*}{5.} & \multirow{2}{*}{$\begin{array}{l}\text { Piezoelectric Voltage constant }\left(10^{-3}\right. \\
\text { volts-meter/ Newton) }\end{array}$} & $-g_{31}$ & 13 \\
\hline & & $\mathrm{g}_{33}$ & 27 \\
\hline
\end{tabular}
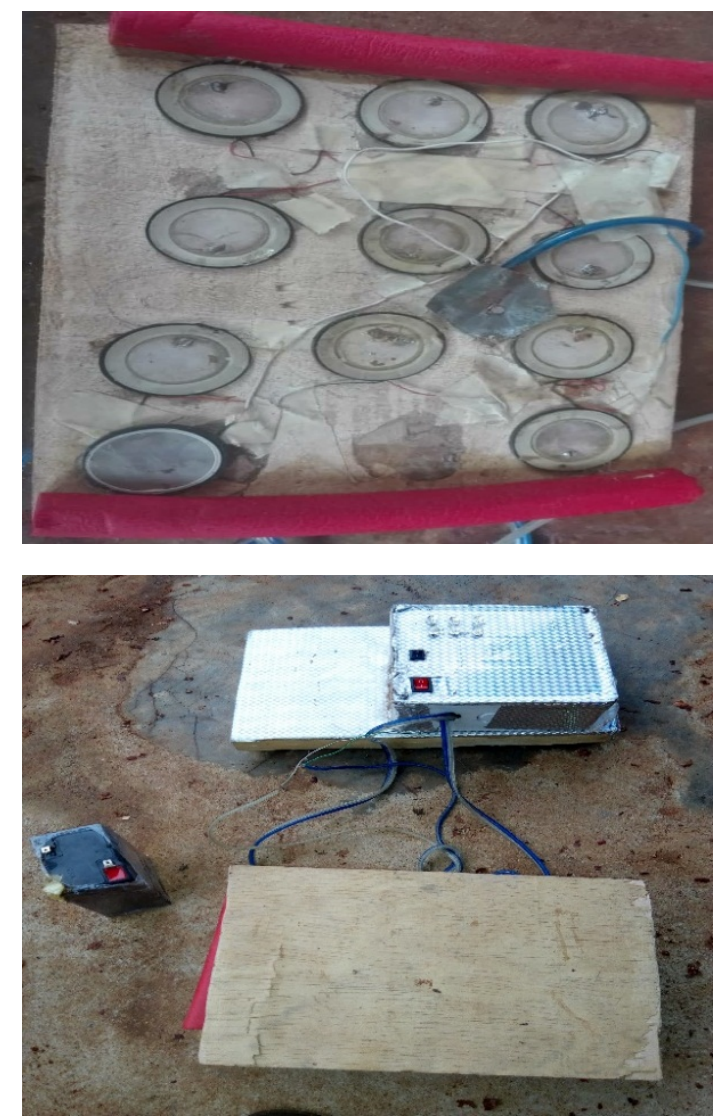
Figure 1. The Arrangement of Piezo Sensors and Connections in the System

Subsequently, series connections were done because the parallel association failed to show important increase within the voltage output. The series connection was used for manufacturing voltage output with high current density. Between the plywood and hard board, a foam spring area unit was placed at the corners and nails area unit placed on the second board such as the sensors at the middle of board in $3 \times 4$ arrangement. Subsequently, the piezoelectric platform was prepared for stepping.

When the dancers step on the platform (plywood) of the system, the plywood will dip down slightly due to the weight of the dancers. The downward movement of the plywood results in generation of electrical power after which the top plywood reverts back to its original position due to negating spring action of the foam provided in the device as in this case.

Usually, the output voltage from a single piezo-sensor was extremely low, therefore combination of 12 piezoelectric is used. Since the output of the piezoelectric material is not a regulated one, variable to linear voltage converter circuit rectifier was used. In this case, AC ripple neutralizer was the circuit used to reduce the ripples from the piezoelectric output. The AC ripple neutralizer consists of rectifier and ripple filter. AC ripples were filtered out using ripple filter and it was used to filter out any further variations in the output and then it can be pass through regulator in order to regulate, and it is constant until the load and mains voltage is kept constant.

Again, the output of the voltage regulator is given to the unidirectional current controller which allows flow of current in only one direction. In this system, diode was used as a unidirectional current controller which main function was to allow the flow of current in only one direction while blocking current in the reverse direction.

Thereafter, a battery was connected to the system to store energy for future use. In this case, a LED display was shown using this foot power. The block diagram of footsteps electricity generation is shown in Figure 2.

As the gadget was placed under the dancing floor, electricity was generated from the pressure from the foot beats of dancers. The electricity generated charged the battery which could be used to energise electrical appliances when the pressure was withdrawn. Multimeter was used to determine the amount of energy generated in the system. as varying forces (foot beats) were applied on the Piezo material, different voltage readings corresponding to the force was displayed. For each such voltage reading across the force sensor, various voltage and current readings of the Piezo material were recorded.

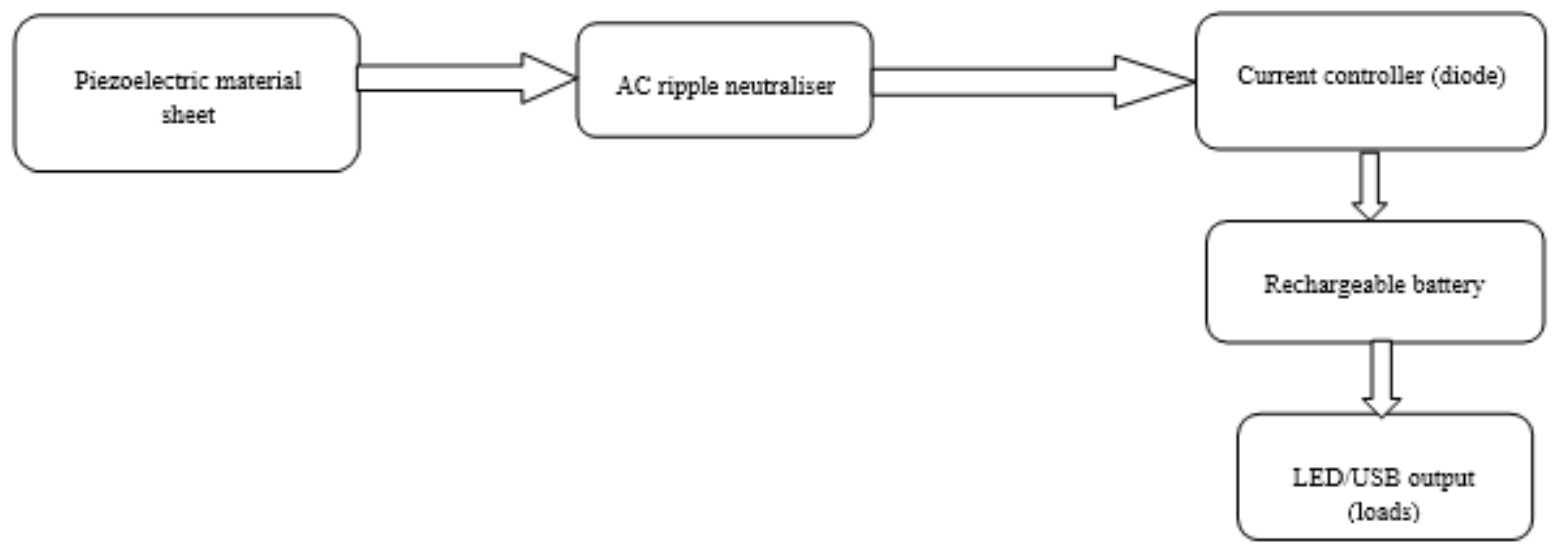

Figure 2. Block Diagram of Footsteps Electricity Generation 


\section{Results and Discussion}

The piezoelectric sensor outputs are presented in Tables 2, 4 and 6. In the design, 12 Piezo electric sensors per one square foot were used. As piezo sensors power generating varies with different foot beats and weights of persons. The gadget was placed under the dancing floor to determine the readings as the number of foot beats increases. Multimeter was connected across for measuring voltages and current. As varying forces were applied on the Piezo material, different voltage readings corresponding to the force were displayed. For each voltage reading across the force sensor, various voltage and current readings of the Piezo material were recorded as presented in Tables 3, 5, and 7.

Table 2. Piezo sensor readings for an average of $50 \mathrm{~kg}$ weight

\begin{tabular}{|c|c|c|c|}
\hline $\begin{array}{c}\text { Piezo } \\
\text { sensor }\end{array}$ & Voltage (mV) & Current (mA) & Power (mW) \\
\hline $\mathbf{1}$ & 0.520 & 0.064 & 0.033 \\
\hline $\mathbf{2}$ & 0.612 & 0.063 & 0.039 \\
\hline $\mathbf{3}$ & 0.560 & 0.064 & 0.036 \\
\hline $\mathbf{4}$ & 0.540 & 0.065 & 0.035 \\
\hline $\mathbf{5}$ & 0.560 & 0.065 & 0.036 \\
\hline $\mathbf{6}$ & 0.600 & 0.062 & 0.037 \\
\hline $\mathbf{7}$ & 0.582 & 0,060 & 0.035 \\
\hline $\mathbf{8}$ & 0.546 & 0.062 & 0.034 \\
\hline $\mathbf{9}$ & 0.522 & 0.061 & 0.032 \\
\hline $\mathbf{1 0}$ & 0.510 & 0.062 & 0.032 \\
\hline $\mathbf{1 1}$ & 0.558 & 0.065 & 0.036 \\
\hline $\mathbf{1 2}$ & 0.552 & 0.061 & 0.034 \\
\hline Average & 0.555 & 0.063 & 0.035 \\
\hline
\end{tabular}

Table 2 showed that one foot beat of an average $50 \mathrm{~kg}$ dancer produced an average Voltage, Current and Power of $0.555 \mathrm{mV}, 0.063 \mathrm{~mA}$ and $0.035 \mathrm{~mW}$ respectively. The power generation of piezo sensor varies with different beats which was as a result of the pressure of the foot beat and the weight of the dancer.

If an average of 0.555 microvolts is produced per foot beat, it would take about 1802 foot beats from the pressure of an average of $50 \mathrm{Kg}$ weight dancer to increase $1 \mathrm{~V}$ charge in battery.

So, to increase $6 \mathrm{~V}$ in a battery as it is in this case, the total number of foot beats needed would be $6 \times 1802=$ 10812 foot beats. Since this would be implemented in a dance hall where foot beats as source of weight were available, it then took an average of 2 foot beats in 1 second.

Extrapolating from Table 2, the average Voltage, Current and Power per beat were $0.555 \mathrm{mV}, 0.063 \mathrm{~mA}$ and $0.035 \mathrm{~mW}$ respectively. However, an increase in the number of beats increased the amount of voltage, current and power generated as shown in Table 3 . There was an upward increment in the amount of voltage added to the battery through charging until the battery was fully charged to its maximum voltage after which the voltage remained stable regardless of any further increase in the number of foot beats.

Table 3. Power generated per foot beat for an average weight of $50 \mathrm{~kg}$ dancer

\begin{tabular}{|c|c|c|c|}
\hline No of Beats & Voltage (mV) & Current (mA) & Power $(\mathbf{m W})$ \\
\hline $\mathbf{1 0 0}$ & 55.50 & 6.30 & 0.35 \\
\hline $\mathbf{2 0 0}$ & 111.00 & 12.60 & 1.40 \\
\hline $\mathbf{3 0 0}$ & 166.50 & 18.90 & 3.15 \\
\hline $\mathbf{4 0 0}$ & 222.00 & 25.20 & 5.59 \\
\hline $\mathbf{5 0 0}$ & 277.50 & 31.50 & 8.74 \\
\hline $\mathbf{6 0 0}$ & 333.00 & 37.80 & 12.59 \\
\hline $\mathbf{7 0 0}$ & 388.50 & 44.10 & 17.13 \\
\hline $\mathbf{8 0 0}$ & 444.00 & 50.40 & 22.38 \\
\hline $\mathbf{9 0 0}$ & 499.50 & 56.70 & 28.32 \\
\hline $\mathbf{1 0 0 0}$ & 555.00 & 63.00 & 34.97 \\
\hline
\end{tabular}

Table 3 principally showed that as the number of foot beats exerting pressure on the gadget increases, there were corresponding increase in the amount of voltage charge in the battery, current and power. However, the increase is not indefinite but up to the maximum voltage of the battery and in this case, 6Volts. The voltage charge in the battery is expected to remains steady regardless of any further increase in the number of foot beats or additional pressure from the foot beats. This is in line with the Ohms law which implies that an increase in the mechanical energy will increase other corresponding parameters such as voltage, current and power as far as the resistance is constant.

Table 4. Piezor sensor readings for an average of $60 \mathrm{~kg}$ weight

\begin{tabular}{|c|c|c|c|}
\hline Piezor sensor & Voltage (mV) & Current $(\mathbf{m A )}$ & Power $(\mathbf{m W})$ \\
\hline $\mathbf{1}$ & 0.680 & 0.080 & 0.054 \\
\hline $\mathbf{2}$ & 0.650 & 0.080 & 0.052 \\
\hline $\mathbf{3}$ & 0.680 & 0.083 & 0.056 \\
\hline $\mathbf{4}$ & 0.645 & 0.080 & 0.052 \\
\hline $\mathbf{5}$ & 0.680 & 0.083 & 0.056 \\
\hline $\mathbf{6}$ & 0.654 & 0.083 & 0.054 \\
\hline $\mathbf{7}$ & 0.650 & 0,080 & 0.052 \\
\hline $\mathbf{8}$ & 0.684 & 0.080 & 0.055 \\
\hline $\mathbf{9}$ & 0.684 & 0.082 & 0.056 \\
\hline $\mathbf{1 0}$ & 0.645 & 0.080 & 0.052 \\
\hline $\mathbf{1 1}$ & 0.680 & 0.083 & 0.056 \\
\hline $\mathbf{1 2}$ & 0.680 & 0.083 & 0.056 \\
\hline Average & 0.668 & 0.081 & 0.054 \\
\hline
\end{tabular}

Table 4 showed that one foot beat of an average 60kg dancer produced an average Voltage, Current and Power of $0.668 \mathrm{mV}, 0.081 \mathrm{~mA}$ and $0.054 \mathrm{~mW}$ respectively. The power generation of piezo sensor varies with different beats which was as a result of the pressure of the foot beat and the weight of the dancer.

Likewise, if an average of 0.668 microvolt was produced per foot beat. it would take about 1498 foot beats from the pressure of an average of $60 \mathrm{Kg}$ weight dancer to increase 1 
$\mathrm{V}$ charge in battery. So, to increase $6 \mathrm{~V}$ in a battery as in this case, the total number of foot beats needed would be 6 $\times 1498=8988$ foot beats.

Extrapolating from Table 4, the average voltage $(0.668 \mathrm{mV})$, current $(0.081 \mathrm{~mA})$ and power $(0.054 \mathrm{~mW})$ respectively, the corresponding increase, current and power due increase in the number of beats were shown in Table 5.

As usual, there was an upward increment in the amount of voltage added to the battery through charging until the battery was fully charged after which the voltage remained stable despite further increase in the number of foot beats. But there was a lesser number of foot beats required to increase 1 unit volt in a battery due to an increase in weight.

Table 5. Power generated per beats for an average weight of $60 \mathrm{~kg}$

\begin{tabular}{|c|c|c|c|}
\hline No of Beats & Voltage (mV) & Current (mA) & Power $(\mathbf{m W})$ \\
\hline $\mathbf{1 0 0}$ & 66.80 & 8.10 & 0.54 \\
\hline $\mathbf{2 0 0}$ & 133.60 & 16.20 & 2.16 \\
\hline $\mathbf{3 0 0}$ & 200.40 & 24.30 & 4.87 \\
\hline $\mathbf{4 0 0}$ & 267.20 & 32.40 & 8.66 \\
\hline $\mathbf{5 0 0}$ & 334.00 & 40.50 & 13.53 \\
\hline $\mathbf{6 0 0}$ & 400.80 & 48.60 & 19.48 \\
\hline $\mathbf{7 0 0}$ & 467.60 & 56.70 & 26.51 \\
\hline $\mathbf{8 0 0}$ & 534.40 & 64.80 & 34.63 \\
\hline $\mathbf{9 0 0}$ & 601.20 & 72.90 & 43.83 \\
\hline $\mathbf{1 0 0 0}$ & 668.00 & 81.00 & 54.12 \\
\hline
\end{tabular}

Table 5 showed that as the number of foot beats exerting pressure on the gadget increases, there were corresponding increment in the amount of voltage charge in the battery, current and power. This was in line with the Ohms law which implies that an increase in the mechanical energy will increase other corresponding parameters such as voltage, current and power as far as the resistance is constant. However, in this case, there was lesser number of foot beats and the amount of time required to increase a unit voltage in the battery due to increase in weight.

Table 6. Piezor sensor readings for an average of $80 \mathrm{~kg}$ weight

\begin{tabular}{|c|c|c|c|}
\hline Piezor sensor & Voltage (mV) & Current (mA) & Power $(\mathbf{m W})$ \\
\hline $\mathbf{1}$ & 0.820 & 0.088 & 0.072 \\
\hline $\mathbf{2}$ & 0.860 & 0.085 & 0.073 \\
\hline $\mathbf{3}$ & 0.840 & 0.088 & 0.074 \\
\hline $\mathbf{4}$ & 0.770 & 0.092 & 0.071 \\
\hline $\mathbf{5}$ & 0.860 & 0.086 & 0.074 \\
\hline $\mathbf{6}$ & 0.840 & 0.089 & 0.075 \\
\hline $\mathbf{7}$ & 0.864 & 0,082 & 0.071 \\
\hline $\mathbf{8}$ & 0.804 & 0.088 & 0.071 \\
\hline $\mathbf{9}$ & 0.866 & 0.090 & 0.078 \\
\hline $\mathbf{1 0}$ & 0.850 & 0.086 & 0.073 \\
\hline $\mathbf{1 1}$ & 0.842 & 0.090 & 0.076 \\
\hline $\mathbf{1 2}$ & 0.840 & 0.083 & 0.074 \\
\hline Average & 0.838 & 0.087 & 0.073 \\
\hline
\end{tabular}

Table 6 showed that one foot beat of an average $80 \mathrm{~kg}$ dancer produced an average voltage, current and power of $0.838 \mathrm{mV}, 0.087 \mathrm{~mA}$ and $0.073 \mathrm{~mW}$ respectively. The power generation of piezo sensor varies with different beats which is as a result of the pressure of the foot beat and the weight of the dancer.

Therefore, if average of 0.838 microvolts was produced per foot beat, it then took about 1194 foot beats from the pressure of an average of $80 \mathrm{Kg}$ weight dancer to increase 1 $\mathrm{V}$ charge in battery. So, to increase $6 \mathrm{~V}$ in a battery as in this case, the total number of foot beats needed would be 6 $\times 1194=7164$ foot beats.

Extrapolating from Table 6 the average voltage $(0.838 \mathrm{mV})$, current $(0.087 \mathrm{~mA})$ and power $(0.073 \mathrm{~mW})$ respectively, the corresponding increase, current and power due increase in the number of beats were shown in Table 7.

As usual, there was an upward increment in the amount of voltage added to the battery through charging until the battery was fully charged after which the voltage remained stable despite further increase in the number of foot beats. But there was a further lesser number of foot beats required to increase 1 unit volt in a battery due to an increase in weight.

Table 7. Power generated per beats for an average weight of $80 \mathrm{~kg}$

\begin{tabular}{|c|c|c|c|}
\hline No of Beats & Voltage (mV) & Current (mA) & Power $(\mathbf{m W})$ \\
\hline $\mathbf{1 0 0}$ & 83.80 & 8.70 & 0.73 \\
\hline $\mathbf{2 0 0}$ & 167.60 & 17.40 & 2.92 \\
\hline $\mathbf{3 0 0}$ & 251.40 & 26.10 & 6.56 \\
\hline $\mathbf{4 0 0}$ & 335.20 & 34.80 & 11.66 \\
\hline $\mathbf{5 0 0}$ & 419.00 & 43.50 & 18.23 \\
\hline $\mathbf{6 0 0}$ & 502.80 & 52.20 & 26.25 \\
\hline $\mathbf{7 0 0}$ & 586.60 & 60.90 & 35.72 \\
\hline $\mathbf{8 0 0}$ & 670.40 & 69.60 & 46.66 \\
\hline $\mathbf{9 0 0}$ & 754.20 & 78.30 & 59.05 \\
\hline $\mathbf{1 0 0 0}$ & 838.00 & 87.00 & 72.91 \\
\hline
\end{tabular}

Table 7 also showed that as the number of foot beats exerting pressure on the gadget increases, there were corresponding increment in the amount of voltage charge in the battery, current and power. Similarly, this was in line with the Ohms law which implies that an increase in the mechanical energy would increase other corresponding parameters such as voltage, current and power as far as the resistance is constant. However, in this case, the number of foot beats and the amount of time required to increase a unit voltage in the battery were much lesser than those of $50 \mathrm{~kg}$ and $60 \mathrm{~kg}$ weights due to increase in weight.

The result of this study depicts that the piezo sensors generate different amount of electricity per number of foot beat as the weight of the dancers varies. The amount of foot beats required to increase a unit voltage in battery also varies as the weight of the dancers varies. For example, it 
would require and 1802 foot beats for a $50 \mathrm{~kg}$ dancer to increase a unit voltage in a battery. Likewise, it would require 1498 foot beats, and 1194 foot beats for $60 \mathrm{~kg}$ and $80 \mathrm{~kg}$ dancers respectively to do the same.

This implies that the voltage, current and power would continue to increase with increase in weight (body mass) of dancers or as a result of addition of dancers on the dancing floor until it reaches a point when the parameters would remain constant even when more weight or pressure is added. At that point, the buttery is assumed to have been fully charged.

This scenario is in line with the general principles of Ohms law which states that electrical current (I) flowing in a circuit is proportional to the Voltage (V) and inversely proportional to the resistance (R), i.e as the voltage increased, the current increased provided the resistance of the circuit remain constant. Implicitly, the results indicate that the body mass (weight) of the dancers is a determining factor in the generation of electricity through the foot beats despite the number of foot beats or the amount of time.

The result of this study strongly shares the same view with Chavan et al. [44], Dhimar et al. [45], and Marshiana et al. [47], but slightly differs from Madhu, et al. [46] who used parallel connections.

\section{Conclusions}

One of the objects of establishing any business venture is to make profit in an environment devoid of any dangers. However, business outfits such as night clubbing that are usually night events are being run with generating sets to provide electricity due to epileptic condition of electricity generation, distribution and supply in Nigeria. Since night clubbing involves locomotion through dances a lot of human energies that could be converted into useful form are being wasted. In view of this, the study has designed and developed a system generating electricity through the beats of human feet that is environmentally, socially and economically sustainable. The system shows that the potential energy in human can be converted into electrical energy through piezoelectric materials.

This system is most suitable where there is high volume of human traffic and especially for small business outfits like club houses, markets, and worship centres, shopping malls, bus stations, parks, etc, could generate the own electricity in the course of running the business. The system is also capable of being used in powering small electrical appliances and electronic gadgets such as cell phones, radio stereo, television, fan, and even powering street lights on the highways through a system whereby vehicles run on the laid piezoelectric materials on the road.

This system of electricity generation is green and does not have any negative environmental consequence, therefore it has added to the search towards sustainable alternative source of energy and electricity generation in
Nigeria. It has provided some useful insights into another area of research in Nigeria gearing towards solving the perennial electricity problems in the country especially for small scale electricity consumers. However, a major drawback in this kind of system is the quantity of energy it generates which is usually very small.

On this strength, research into this kind of system of electricity generation should be expanded in large scale and supported by the government or corporate organisations. As new technology in building and construction industry evolves, this system should also be incorporated in the design and construction of building as a means of achieving sustainable construction.

Likewise, effort towards sustainable building in Nigeria should also involve the specification and use of sustainable building materials such as piezoelectric floor tiles as being done in India and other developed countries; this will minimise the amount conventional energy consumption in the building use.

\section{REFERENCES}

[1] M. Kanagawa, T. Nakata. Assessment of access to electricity and the socio-economic impacts in rural areas of developing countries, Energy Policy, Vol. 36, No. 6, 2016-2029, 2008. https://doi.org/10.1016/j.enpol.2008.01.041.

[2] A. A. Ogundipe, O. Akinyemi, O. M. Ogundipe. Electricity Consumption and Economic Development in Nigeria, International Journal of Energy Economics and Policy, Vol. 6, No. 1, 134-143, 2016.

[3] T. Zhang, X. Shi, D. Zhang, J. Xiao. Socio-economic development and electricity access in developing economies: A long-run model averaging approach, Energy Policy, Vol. 132, 223-231, 2019. https://doi.org/10.1016/j. enpol.2019.05.031.

[4] S. O. Oyedepo, O. P. Babalola, S. C. Nwanya, O. Kilanko, R. O Leramo, A. K. Aworinde, T. Adekeye, J. A. Oyebanji, A. O. Abidakun, O. L. Agberegha. Towards a Sustainable Electricity Supply in Nigeria: The Role of Decentralized Renewable Energy System. European Journal of Sustainable Development Research, Vol. 2, No, 4, 40, 2018. https://doi.org/10.20897/ejosdr/3908.

[5] A. S. Oyewo, A, Aghahosseini, D. Bogdanov, C. Breyer. Pathways to a fully sustainable electricity supply for Nigeria in the mid-term future, Energy Conversion and Management, Vol. 178, 44-64, 2018. https://doi.org/10.101 6/j.enconman.2018.10.036.

[6] A. S. Aliyu, J. O. Dada, I. K. Adam. Current status and future prospects of renewable energy in Nigeria, Renewable and Sustainable Energy Reviews, Vol. 48, 336-346, 2015. http://dx.doi.org/10.1016/j.rser.2015.03.098.

[7] A. S. Sambo, B. Garba, I. H. Zarma, M. M. Gaji. Electricity generation and the present challenges in the Nigerian power sector, Journal of Energy and Power Engineering, Vol. 6, No. 7, 1050-1059, 2012. DOI: 10.17265/1934-8975/2012.0 
7.005 .

[8] E. I. Ohimain. Diversification of Nigerian Electricity Generation Sources, Energy Sources, Part B: Economics, Planning, and Policy, Vol. 10, No. 3, 298-305, 2015. https://doi.org/10.1080/15567249.2010.551249.

[9] S. O. Oyedepo. Energy and sustainable development in Nigeria: the way forward, Energy, Sustainability and Society, Vol. 2, No. 15, 2012. https://doi.org/10.1186/2192-0567-2-15.

[10] A. S. Sambo. Matching Electricity Supply with Demand in Nigeria, International Association for Energy Economics, Fourth Quarter, 32-36, 2008.

[11] Federal Ministry of Power. The Nigerian Power Sector Investment Opportunities and Guidelines, Federal Republic of Nigeria Draft, 2016. https://www.nigeriaelectricityhub.c om/download/the-nigerian-power-sector-investment-oppor tunities-and-guidelines-draft-2016/.

[12] Advisory Power Team, Nigeria Power Baseline Report. Report developed by the Advisory Power Team, Office of the Vice President, Federal Government of Nigeria in conjunction with Power Africa, 3-30, 2015.www.nesistats. org.

[13] M. Abbas, A. Jibrilla. Impact of power (electricity) supply on the performance of small and medium scale enterprises in Adamawa state: Case study Mubi north local government area, International Journal of Humanities and Social Science Research, Vol. 2, No. 12, 04-13, 2016.

[14] C. O. Olaoye, A. O. Talabi. The Effect of Electricity Tariff and Self-Generated Power Supply on Business Performance in Nigeria, Research Journal of Finance and Accounting, Vol. 9, No. 20, 74-80, 2018.

[15] A. Sabo, O. K. Lekan. Electricity Supply and Performance of Small and Medium Enterprises in Nigeria: Assessing Selected Firms in North-Western States, World Journal of Innovative Research (WJIR), Vol. 6, No. 4, 91-99, 2019.

[16] O. D. Olatunji. Electricity Insecurity and the Performance of Small Scale Businesses in Akoko Area of Ondo State, Nigeria, International Journal of Business and Social Science, Vol. 10, No. 7, 158-167, 2019. doi:10.30845/ijbss .v10n7p17.

[17] Nigerian Energy Support Programme (NESP). The Nigerian Energy Sector: An Overview with a Special Emphasis on Renewable Energy, Energy Efficiency and Rural Electrification, 2nd Edition, Deutsche Gesellschaft für/Federal Ministry of Power Abuja, Nigeria, 2015. https://www.giz.de/en/downloads/giz2015-en-nigerian-ene rgy-sector.pdf.

[18] A. Adhithan, K. Vignesh, M. Manikandan. Proposed Method of Foot Step Power Generation Using Piezo Electric Sensor, International Advanced Research Journal in Science, Engineering and Technology, Vol. 2, 25-27, 2015.

[19] C. K. Ang, A. A. Al-Talib, S. M. Tai, W. H. Lim. Development of a footstep power generator in converting kinetic energy to electricity, 2018 International Conference on Renewable Energy and Environment Engineering (REEE 2018), Paris, France, Vol.80, 2019. https://doi.org/ 10.1051/e3sconf/20198002001.
[20] A.S. Babu, D. Joseph, G. Harikrishnan, S. M. Raj. Foot Step Power Generation-Power Generating Slabs, International Journal of Engineering Science Invention, Vol. 8, No. 6, 4-10, 2019.

[21] S. Chavhan, S. Bhong, P. Patil, A. Shrivastav. Power Generation Using Footstep, International Journal of Recent Research in Electrical and Electronics Engineering (IJRREEE), Vol. 2, No. 2, 136-140, 2015.

[22] H. R. Nayan. Power Generation Using Piezoelectric Material, Research Article of Material Science \& Engineering, Vol. 4, No. 3, 1-4, 2015.

[23] M. A. Saeed, N. Zaffar, M. H.Tahir, A. Malik. Design of Footstep Power Generation System Using Rack and Pinion Gears Mechanism, International Journal of Engineering Applied Sciences and Technology, Vol. 4, No. 2, 48-52, 2019.

[24] A. Shiraz, H. Farrukh, Power Generation Footstep, International Journal of Advancements in Research \& Technology, Vol. 3, No. 4, 1-3, 2014.

[25] J. Ben-Iwo, V. Manovic, P. Longhurst. Biomass resources and biofuels potential for the production of transportation fuels in Nigeria, Renewable and Sustainable Energy Reviews, Vol. 63, 172-192, 2016.https://doi.org/10.1016/j. rser.2016.05.050

[26] Y. S. Mohammed, W. M. Mustafa, N. Bashir, A. S. Mokhtar. Renewable energy resources for distributed power generation in Nigeria: A review of the potential, Renewable and Sustainable Energy Reviews, Vol. 22, 257-268, 2013. https://doi.org/10.1016/j.rser.2013.01.020.

[27] N. I. Nwulu, O. P. Agboola. Utilizing Renewable Energy Resources to Solve Nigeria's Electricity Generation Problem, International Journal of Thermal \& Environmental Engineering, Vol. 3, No. 1, 15-20, 2011.

[28] J. O. Oji, N. Idusuyi, T. O. Aliu, M. O. Petinrin, O. A. Odejobi, A. R. Adetunji. Utilization of solar energy for power generation in Nigeria, International Journal Energy Engineering, Vol. 2, No. 2, 54-59, 2012. doi: 10.5923/j.ije e.20120202.07.

[29] S. O. Oyedepo. Towards achieving energy for sustainable development in Nigeria, Renewable and Sustainable Energy

Reviews, 34, 255-272, 2014. https://doi.org/10.1016/j.rser. 2014.03.019.

[30] S. S. Paul, S. O. Oyedepo, M. O. Adaramola. Economic assessment of water pumping systems using wind energy conversion systems in the southern part of Nigeria, Energy Exploration Exploitation, Vol. 30, No. 1, 1-18, 2012. https://doi.org/10.1260/0144-5987.30.1.1.

[31] A. S. Sambo. Strategic developments in renewable energy in Nigeria, International Association for Energy Economics, Third Quarter, 15-19, 2009.

[32] M. Shaaban, J. O. Petinrin. Renewable energy potentials in Nigeria: Meeting rural energy needs, Renewable and Sustainable Energy Reviews, Vol. 29, 72-84, 2014. https://doi.org/10.1016/j.rser.2013.08.078.

[33] A. S. Sambo. Renewable energy electricity in Nigeria: The way forward, Renewable Electricity Policy Conference, Abuja, Nigeria, December 11-12, 2006. 
[34] P. Kamlesh, P. Krunal, P. Ronak, P. Jaydeep, S. Mehul. Design of Foot Step Power Generation System: An Investigation on Generation of Electricity Using Foot Step, $2^{\text {nd }}$ International Conference on Current Research Trends in Engineering and Technology, Vol. 4, No. 5, 655-660, 2018.

[35] T. Al-Qadhi, A.Al-Baser, F. Sammani, M. Elsayed, T. Jamil. Energy harvesting and power generation from stairs, AIP Conference Proceedings, Vol. 2035, No. 1, 060008, 2018. https://doi.org/10.1063/1.5075588

[36] R. Sabarish, A. Kumar. Design and Fabrication of Foot Step Power Generation, International Journal of Pure and Applied Mathematics, Vol. 116, No. 19, 529-533, 2017.

[37] A. Upadhyaya, S. Upadhyaya. A Proposed Method to Generate Electricity through Power Stair, American Journal of Engineering Research (AJER), Vol. 5, No. 6, 20-23, 2016.

[38] N. Abhishek, Y. Shivasharana. Power generation by Foot Steps Using Rack and Pinion Arrangement, International Journal of Engineering Research and Advanced Technology, Vol. 2, No. 1, 10-14, 2016.

[39] P. A. Bhosale, H. Shinde, R. Tahade, M. Valani, R. Wallalwar. Design of Foot Step Power Energy Generation Machine, International Conference on Ideas, Impact and Innovation in Mechanical Engineering (ICIIIME 2017), Vol.5 No. 6, 943-948.

[40] A. R. Kotadiya, B. D. Parmar. Modification and implementation of foot step power generation System in weighting scale of the gym, Journal of Engineering Development and Research, Vol. 6, No. 3, 373-376, 2018.

[41] B. Munaswamy, C. Prudhvi, V. Srikanth, B. Kirankumar, E. P. Kumar. Mechanical Footstep Power Generation, International Journal of Engineering Trends and Applications (IJETA), Vol. 5, No. 2, 291-298, 2018.

[42] S. K. Sahoo, S. kumar, P. K. Yadav, R. Kumar. Foot Step Power Generation. International Journal of Mechanical Engineering and Technology, Vol. 7, No. 2, 187-190, 2016.

[43] M. A. Aman, H. U. Afridi, M. Z. Abbasi, A. Khan, M. Salman. Power Generation from Piezoelectric Footstep Technique, Journal of Mechnics of Continua and Mathematical Sciences, Vol. 13, No. 4, 67-72, 2018. https://doi.org/10.26782/jmcms.2018.10.00006.

[44] A. Chavan, S. Lakhadive, V. Pondhe, V. Philip. Advanced Foot Step Power Generation Using Piezo-Electric Sensors, International Journal of Advance Research, Ideas and Innovations in Technology, Vol. 3, No. 2, 2017.

[45] K. Dhimar, K. Patel, Z. Patel, N. Pindiwala. Footstep Power Generation System, International Research Journal of Engineering and Technology, Vol. 4, No. 4, 1214-1219, 2017.

[46] P. Madhu, S. Pradeep, D. Mallappa, H. Manjunath, N. Ningappa, M. Prashant. Electrical Power Generation by Foot-steps using Piezo-electric Transducers, International Journal of Recent Trends in Engineering \& Research (IJRTER), Vol. 2, No. 6, 2016.

[47] D. Marshiana, E. M. Sherine, N. Sunitha, C. Vinothkumar. Footstep Power production using Piezoelectric Sensors, Research Journal of Pharmacy and Technology, Vol. 9, No.

\section{7, 831-834, 2016. DOI:10.5958/0974-360X.2016.00157.8.}

[48] M. J. Anooj, B. Jithin, R. Ashwin, T. P. Eldho, V. Jimson. Footstep Power Generation Using Piezo Electric Transducers, International Journal of Advanced Research in Electrical, Electronics and Instrumentation Engineering, Vol. 6, No. 3, 1896-1902, 2017. DOI:10.15662/IJAREEIE. 2017.0603126

[49] R. Gopinath, M. Lavanya, M. Arivalagan. Power Generating Using Human Foot Step with Pizeo Electric Sensor and Treadmill, International Journal of Pure and Applied Mathematics Vol. 119, No. 16, 3171-3182, 2018.

[50] K. Naresh, A. Balaji, M. Rambabu, G. Nagaraju. Practical Oriented Foot Step Electric Power Generation by Using Piezo Material and Microcontroller in Campus, International Research Journal of Engineering and Technology, Vol. 5, No. 7, 1590-1596, 2018.

[51] G. Hofstede. Cultures and Organisations: Software of the Mind, McGraw Hill, London, 1991.

[52] M. G. Kang, W. S. Jung, C. Y. Kang, S. J. Yoon. Recent Progress on PZT Based Piezoelectric Energy Harvesting Technologies. Actuators, Vol. 5, No. 1, 5, 2016. https://doi .org/10.3390/act5010005

[53] M. Kim, B. Hwang, J. Jeong, N. K. Min, K. H. Kwon. Micromachining of a Bimorph $\mathrm{Pb}(\mathrm{Zr}, \mathrm{Ti}) \mathrm{O}_{3} \quad(\mathrm{PZT})$ Cantilever using a Micro-Electromechanical Systems (MEMS) Process for Energy Harvesting Application, Journal of Nanoscience and Nanotechnology, Vol. 12, No. 7, 6011-6015, 2012. https://doi.org/10.1166/jnn.2012.6365.

[54] V. V. Petrov. Harvester of Energy on $\mathrm{Pb}(\mathrm{Zr}, \mathrm{Ti}) \mathrm{O}_{3}$ Thin Films, Proceedings, Vol. 4, No. 1, 40, 2019.), 40; https://d oi.org/10.3390/ecsa-5-05870. 